\title{
Effect of high and low molecular weight glutenin subunits, and subunits of gliadin on physicochemical parameters of different wheat genotypes
}

\author{
Efeito das subunidades de glutenina de alto e baixo peso molecular e das subunidades \\ de gliadina sobre os parâmetros físico-químicos de diferentes genótipos de trigo
}

\author{
Mariana Souza COSTA ${ }^{1}$, Maria Brígida dos Santos SCHOLZ ${ }^{2}$, Célia Maria Landi FRANCO ${ }^{1 \star}$
}

\begin{abstract}
Identification of functional properties of wheat flour by specific tests allows genotypes with appropriate characteristics to be selected for specific industrial uses. The objective of wheat breeding programs is to improve the quality of germplasm bank in order to be able to develop wheat with suitable gluten strength and extensibility for bread making. The aim of this study was to evaluate 16 wheat genotypes by correlating both glutenin subunits of high and low molecular weight and gliadin subunits with the physicochemical characteristics of the grain. Protein content, sedimentation volume, sedimentation index, and falling number values were analyzed after the grains were milled. Hectoliter weight and mass of 1000 seeds were also determined. The glutenin and gliadin subunits were separated using polyacrylamide gel in the presence of sodium dodecyl sulfate. The data were evaluated using variance analysis, Pearson's correlation, principal component analysis, and cluster analysis. The IPR 85, IPR Catuara TM, T 091015, and T 091069 genotypes stood out from the others, which indicate their possibly superior grain quality with higher sedimentation volume, higher sedimentation index, and higher mass of 1000 seeds; these genotypes possessed the subunits 1 (Glu-A1), $5+10$ (Glu-D1), $c$ (Glu-A3), and $b$ (Glu-B3), with exception of T 091069 genotype that possessed the $g$ allele instead of $b$ in the Glu-B3.
\end{abstract}

Keywords: wheat quality; proteins; physicochemical tests.

\section{Resumo}

A identificação das propriedades funcionais de farinhas de trigo através de testes específicos possibilita selecionar genótipos de trigo com características adequadas a cada uso industrial. O principal objetivo dos programas de melhoramento genético é melhorar a qualidade do banco de germoplasma para que seja possível desenvolver trigos com força de glúten e extensibilidade adequadas para produção de produtos panificáveis. O objetivo deste estudo foi avaliar 16 genótipos de trigo correlacionando as subunidades de gluteninas de alto e baixo peso molecular e as subunidades de gliadinas com as características físico-químicas do grão. Foram determinados o teor de proteína, volume de sedimentação, índice de sedimentação e número de queda. O peso hectolitro e massa de 1000 sementes também foram determinados. As subunidades de gluteninas e gliadinas foram separadas usando gel de poliacrilamida na presença do dodecil sulfato de sódio. Os dados foram submetidos à análise de variância, correlação de Pearson, análise de componentes principais e análise de cluster. Os genótipos IPR 85, IPR Catuara TM, T 091015 e T 091069 se destacaram dos demais, evidenciando possível superioridade na qualidade do grão, apresentando maior volume de sedimentação, índice de sedimentação e peso de mil sementes, e apresentaram em sua constituição as subunidades 1 (Glu-A1), $5+10$ (Glu-D1), $c$ (Glu-A3) e $b$ (Glu-B3), com exceção do genótipo T 091069, que apresentou o alelo $g$ em vez do $b$ no Glu-B3.

Palavras-chave: qualidade de trigo; proteínas; testes físico-químicos.

\section{Introduction}

Wheat (Triticum aestivum L.) has a great economic and nutritional importance; for that reason, it is the most widely produced and consumed cereal grain in the world. The technological quality of wheat can be defined as the result of the interaction between different factors, such as the genetic potential of the cultivar, the effects of soil conditions and climate, the susceptibility to pests and diseases, and the ease of crop management, harvesting, drying, and storage (GUARIENTI, 1996; SHEWRY et al., 2003). Gluten proteins, glutenins, and gliadins, are the most important components of wheat kernels. Together, they provide viscoelasticity to the dough, which defines its bread-making quality (HOSENEY, 1991; KTENIOUDAKI; BUTLER; GALLAGHER, 2011).

The main rheological properties of gluten are elasticity and extensibility. The adequate equilibrium between these two properties is a characteristic of wheat gluten that makes it adequate for bread making. Elasticity determines the stretching abilities of the dough when it is subjected to a force. It determines the extent to which the dough returns to its initial form when this force is removed. Conversely, extensibility is a property of stretching in the direction of the applied force, and it determines 
the extent to which the dough remains in this final position without the breakdown of its structure (GUTKOSKI, 2009).

The SDS-PAGE electrophoresis test is a traditional method used for separating protein components. It allows the separation of the subunits from gluten proteins by detecting the glutenin subunits of both high molecular weight (HMW-GS) and low molecular weight (LMW-GS) (PAYNE et al., 1987; GUPTA; BEKES; WRIGLEY, 1991; GUPTA et al., 1994).

Genes that encode the HMW-GS are located at the Glu-A1, Glu-B1, and Glu-D1 loci on the long arms of the A1, B1, and D1 chromosomes, respectively (PAYNE et al., 1984), and those that encode the LMW-GS are located at the Glu-A3, Glu-B3, and Glu-D3 loci on the short arms of the A1, B1, and D1 chromosomes, respectively (WEEGLES; HAMER; SCHOFIELD, 1996).

Studies have shown that the HMW-GS have the highest influence on the rheological properties of dough and breadmaking quality (PEÑA et al., 2005; OURY et al., 2009; LI et al., 2010; ZHENG et al., 2011; HERNÁNDEZ et al., 2012). The alleles 1 and $2^{*}$ of Glu-A1 have been found to have a better effect on bread-making quality when compared to a null allele (GUPTA et al., 1994; HE et al., 2005). The $5+10$ alleles of the Glu-D1 are correlated with higher dough strength, whereas the $2+12$ alleles are correlated with low bread-making quality (BRANLARD; DARDEVET, 1985; GIANIBELLI et al., 2001). However, in the case of LMW-GS, the Glu-A3 $b$ subunit has been found to have a positive effect on sedimentation volume and sedimentation index, whereas the $\mathrm{g}$ allele of the Glu-B3 has been found to have a better effect on sedimentation volume and gluten strength (LIANG et al., 2010).

In breeding programs, the main objective is to improve the quality of the germplasm bank in order to make it possible to develop wheat with adequate gluten strength and extensibility for bread-making. Rheological and bread-making tests are laborious and require significant amounts of time and large quantities of samples, conditions which are inadequate for the needs of breeding programs. Therefore, the identification of flour properties using rapid and specific tests for each different type of product allows the selection of cultivars with appropriate characteristics for each industrial use in less time, ensuring the acceptability and success of the new cultivar.

The aim of this study was to evaluate 16 wheat genotypes from the crossing blocks of the IAPAR by correlating the HMWGS, LMW-GS and gliadin subunits with the physicochemical characteristics of the grains.

\section{Materials and methods}

In this study, 16 wheat (Triticum aestivum L.) genotypes ( 4 of which were cultivars and 12 were lines) from the crossing blocks of the IAPAR were used. The seeds were sowed and harvested in an experimental station in the city of Londrina, $\mathrm{PR}$, Brazil. The harvest of plots was completed after the grains matured (phenological stage 11.4 on the Feekes scale). All samples were dried outdoors at ambient temperature $(\sim 10.05 \%$ moisture), and the grains were stored at $4{ }^{\circ} \mathrm{C}$ for later use.

\subsection{Milling of grains}

Wheat grains of each genotype were milled in a hammer mill (Perten Laboratory Mill 3100) to pass through a $0.8-\mathrm{mm}$ sieve. From this wholemeal flour, the protein content, sedimentation volume, and falling number values were determined. The analyses were performed in triplicate.

\subsection{Protein content}

Nitrogen content was determined according to the 46-13 method of the Approved Methods of the American Association of Cereal Chemists (AMERICAN..., 2000). A correction factor of 5.7 was used to calculate total protein content.

\subsection{SDS- sedimentation volume}

SDS-sedimentation volume was determined using the method outlined by Peña et al. (1990). The SDS-lactic acid reagent was prepared by dissolving $20 \mathrm{~g}$ of SDS in $1 \mathrm{~L}$ of water and adding $20 \mathrm{~mL}$ of stock diluted lactic acid solution (one part lactic acid plus eight parts water by volume). Next, $1 \mathrm{~g}$ of whole meal flour was briefly placed in a $25-\mathrm{mL}$ graduated cylinder, $6 \mathrm{~mL}$ water containing Coomasie Brilliant Blue R250 was added, and the cylinder was vortexed for $5 \mathrm{~min}$. Then, $19 \mathrm{~mL}$ of the SDSlactic acid reagent was added, and the content of the cylinders was mixed for $5 \mathrm{~min}$. Finally, the cylinders were put in a vertical position, and the sedimentation volume was determined $14 \mathrm{~min}$ later. The sedimentation index was calculated as the relationship between the sedimentation volume and the protein content.

\subsection{Falling number values}

Falling number values were determined using a falling number device (FN 1500 - Perten Instruments), according to the 56-81 B method of the AACC (AMERICAN..., 2000).

\subsection{Mass of 1000 seeds}

The mass of 1000 seeds was obtained by counting and weighting 100 wheat seeds in eight replicates. The average of these measures was multiplied by 10 in order to calculate the mass of 1000 seeds (BRASIL, 2009).

\subsection{Hectoliter weight}

The mass of $100 \mathrm{~L}$ of grains expressed in $\mathrm{kg} / \mathrm{hL}$ was determined using a G800 grain moisture meter (GEHAKA AGRI).

\subsection{SDS-PAGE analysis}

Glutenins and gliadins were separated, and HMW-GS, LMW-GS and subunits of gliadins were analyzed using SDSPAGE according to Peña, González and Cervantes (2004). The nomenclature used by Payne et al. (1987) was also used for HMW-GS (Glu-A1, Glu-B1, Glu-D1), and the nomenclature used by Singh, Shepherd and Cornish (1991) and Branlard et al. (2003) was used for LMW-GS (Glu-A3, Glu-B3). Scores from 1 to 4 were calculated for each HMW-GS, and the Total Score (TS) 
was represented by the sum of the scores of Glu-A1, Glu-B1, and Glu-D1. Each genotype may present a minimum and maximum TS of 4 and 10, respectively (PAYNE et al., 1987).

\subsection{Statistical analysis}

Variance analysis (ANOVA) was performed using Statistica 7.0 software (STATSOFT, 2007), and a comparison of the means was performed using the Tukey test $(p \leq 0.05)$ using the same software.

Pearson's correlation, principal components analysis, and cluster analysis were performed using XLSTAT, version 2008.4.02.

\section{Results and discussion}

\subsection{Physicochemical characterization of the wheat grains}

Bread wheat quality may be classified by its protein content (PC) as very low ( $\leq 9.0 \%)$, low (9.1-11.5\%), medium (11.6-13.5\%), high (13.6-15.5\%), very high (15.6-17.5\%), and extra high $(\geq 17.6 \%)$ (WILLIAMS et al., 1988). The PC of different genotypes varied from 13.7 to $17.9 \%$ (Dry basis) (Table 1), and they can be classified as high or extra high in quality. There was a significant difference in the PC of the grains due to the diversity of the materials studied.

Gluten strength may be evaluated by the volume of sedimentation (SDS-SV) in weak gluten $(\leq 12.0 \mathrm{~mL}$ ), intermediatestrength gluten (12.5-18.5 mL), strong gluten (19.0-21.0 mL), and very strong gluten $(\geq 21.5 \mathrm{~mL})$ (MANDARINO, 1993). The SDS-SV of different genotypes varied from 8.3 to $14.6 \mathrm{~mL}$ (Table 1). The IAPAR 78, T 091028, IPR 130, and T 091006

Table 1. Physicochemical parameters of the wheat grains.

\begin{tabular}{lcccccc}
\hline \multicolumn{1}{c}{ Genotype } & $\begin{array}{c}\text { PC } \\
(\%)\end{array}$ & $\begin{array}{c}\text { SDS-SV } \\
(\mathrm{mL})\end{array}$ & SI & $\begin{array}{c}\text { FN } \\
(\mathrm{sec})\end{array}$ & $\begin{array}{c}\text { MTS } \\
(\mathrm{g})\end{array}$ & $\begin{array}{c}\text { HW } \\
(\mathrm{Kg} / \mathrm{hL})\end{array}$ \\
\hline IAPAR 78 & $14.4^{\mathrm{f}}$ & $8.3^{\mathrm{h}}$ & 0.58 & $551^{\mathrm{f}}$ & $41.1^{\mathrm{ef}}$ & $82.7^{\mathrm{a}}$ \\
IPR 130 & $13.7^{\mathrm{g}}$ & $10.8^{\mathrm{g}}$ & 0.79 & $480^{\mathrm{g}}$ & $39.6^{\mathrm{fg}}$ & $80.2^{\mathrm{c}}$ \\
IPR 85 & $14.7^{\mathrm{f}}$ & $13.8^{\mathrm{bc}}$ & 0.94 & $538^{\mathrm{f}}$ & $50.5^{\mathrm{a}}$ & $82.3^{\mathrm{ab}}$ \\
IPR Catuara TM & $14.5^{\mathrm{f}}$ & $14.2^{\mathrm{ab}}$ & 0.98 & $604^{\mathrm{de}}$ & $45.0^{\mathrm{bc}}$ & $80.8^{\mathrm{bc}}$ \\
LD 101108 & $16.4^{\mathrm{c}}$ & $13.1^{\mathrm{cd}}$ & 0.80 & $619^{\mathrm{cd}}$ & $35.1^{\mathrm{hi}}$ & $80.7^{\mathrm{bc}}$ \\
T 081099 & $15.1^{\mathrm{e}}$ & $12.3^{\mathrm{ef}}$ & 0.81 & $539^{\mathrm{f}}$ & $32.5^{\mathrm{j}}$ & $80.7^{\mathrm{bc}}$ \\
T 091006 & $14.3^{\mathrm{f}}$ & $11.9^{\mathrm{f}}$ & 0.83 & $468^{\mathrm{g}}$ & $38.6^{\mathrm{g}}$ & $80.3^{\mathrm{c}}$ \\
T 091008 & $15.9^{\mathrm{d}}$ & $12.9^{\mathrm{de}}$ & 0.81 & $679^{\mathrm{ab}}$ & $33.5^{\mathrm{jj}}$ & $79.6^{\mathrm{cde}}$ \\
T 091015 & $15.0^{\mathrm{e}}$ & $14.0^{\mathrm{ab}}$ & 0.94 & $582^{\mathrm{def}}$ & $43.8^{\mathrm{cd}}$ & $77.9^{\mathrm{defg}}$ \\
T 091027 & $17.4^{\mathrm{b}}$ & $14.6^{\mathrm{a}}$ & 0.84 & $657^{\mathrm{abc}}$ & $45.9^{\mathrm{b}}$ & $78.9^{\text {cdef }}$ \\
T 091028 & $14.6^{\mathrm{f}}$ & $9.0^{\mathrm{h}}$ & 0.62 & $666^{\mathrm{abc}}$ & $40.9^{\mathrm{f}}$ & $79.1^{\text {cdef }}$ \\
T 091031 & $17.0^{\mathrm{b}}$ & $12.3^{\mathrm{ef}}$ & 0.72 & $601^{\mathrm{de}}$ & $42.8^{\mathrm{de}}$ & $77.9^{\mathrm{defg}}$ \\
T 091033 & $16.5^{\mathrm{c}}$ & $12.9^{\mathrm{de}}$ & 0.78 & $466^{\mathrm{g}}$ & $41.5^{\mathrm{ef}}$ & $79.7^{\mathrm{cd}}$ \\
T 091056 & $17.9^{\mathrm{a}}$ & $12.1^{\mathrm{ef}}$ & 0.68 & $630^{\mathrm{bcd}}$ & $35.7^{\mathrm{h}}$ & $76.6^{\mathrm{g}}$ \\
T 091069 & $13.9^{\mathrm{d}}$ & $14.0^{\mathrm{ab}}$ & 1.01 & $564^{\mathrm{ef}}$ & $37.7^{\mathrm{g}}$ & $77.7^{\mathrm{fg}}$ \\
T 091088 & $17.1^{\mathrm{b}}$ & $13.5^{\mathrm{bcd}}$ & 0.79 & $700^{\mathrm{a}}$ & $35.6^{\mathrm{h}}$ & $77.8^{\mathrm{efg}}$ \\
\hline
\end{tabular}

${ }^{a}$ Average of three replicates. Values in the same column followed by a different letter are significantly different $(\mathrm{p} \leq 0.05)$. PC: Protein content (dried basis). FN: Falling number. SDS-SV: Sedimentation volume. SI: Sedimentation index. MTS: Mass of 1000 seeds. HW: Hectoliter weight. genotypes had weak gluten strength, whereas the other samples possessed intermediate gluten strength.

The sedimentation index (SI) of the genotypes varied from 0.58 to 1.01 (Table 1), and there was a strong correlation between the index values and the volume of sedimentation $(\mathrm{r}=0.827)$. According to SI, the genotypes were classified into three distinct groups: the first one is comprised of IAPAR 78, T 091056, T 091031, and T 091028 genotypes that had low SIs (0.58-0.72); the second one is comprised of T 091008, T 091088, T 091027, LD 101108, T 091033, T 081099, T 091006, and IPR 130 genotypes that had intermediate SIs $(0.78-0.84)$, and the last one is comprised of the T 091015, T 091069, IPR 85, and IPR Catuara TM genotypes that showed high SI (0.94-1.01).

Falling Number (FN) is a fast method used to indirectly measure the $\alpha$-amylase activity in wheat flour (PRABHASANKAR; SUDHA; RAO, 2000). The FN of the grains varied from 466 to 700 seconds (Table 1), results which indicate low enzymatic activity for all samples. Wheat with very low enzymatic activity may be used in mixtures with other wheat with very high amilolytic activity.

The mass of 1000 seeds (MTS) varied from 32.5 to $50.5 \mathrm{~g}$ (Table 1). According to Williams et al. (1988), wheat can be classified as a very small mass (15-25 g), a small mass (26-35 g), a medium mass (36-45 g), a large mass (46-54 g), and a very large mass ( $\geq 55 \mathrm{~g}$ ). The IPR 85 cultivar had the largest MTS, whereas the T 081099 line had the smallest. According to this classification, the IPR 85 cultivar is the only one that can be classified as large, and all others were classified as medium.

The hectoliter weight (HW) is used in Brazil for classifying wheat into types, and $78.0 \mathrm{~kg} / \mathrm{hL}$ is the minimum weight required to be classified as Type 1 (BRASIL, 2010). The HW of the genotypes varied from 76.6 to $82.7 \mathrm{~kg} / \mathrm{hL}$ (Table 1). The lines known as T 091056, T 091069, T 091088, T 091031, and T 091015 had HWs, which were lower than $78.0 \mathrm{~kg} / \mathrm{hL}$, and were therefore classified as Type 2. The IAPAR 78 genotype had a HW that was significantly ( $\mathrm{p} \leq 0.05)$ higher than that of the others $(82.7 \mathrm{~kg} / \mathrm{hL})$. These results agree with those found by Costa et al. (2008), who found HW from 74.7 to $80.0 \mathrm{~kg} / \mathrm{hL}$, and Gutkoski et al. (2008), who found HW from 74.3 to $80.1 \mathrm{~kg} / \mathrm{hL}$ for different wheat genotypes.

Pearson's correlation between analyzed parameters showed a negative correlation $(\mathrm{r}=-0.509)$ between HW and PC. This result suggests that although the HW is used as an important parameter in wheat commercialization, it is not efficient as the sole method for determining the wheat bread-making characteristics. There was no correlation between HW and MTS either, results which are consistent with those of Smanhotto et al. (2006). Schmidt et al. (2005) did not observe any correlation between the HW and the other grain characteristics, such as PC in the grain and in the flour, volume of sedimentation, energy of dough deformation (W), total score determined using SDSPAGE, and mixography.

\subsection{Composition of HMW-GS and LMW-GS}

The HMW-GS coded by the Glu-A1, Glu-B1, and Glu-D1 loci were observed at the top of the glutenin gel, while the LMW- 
GS coded by Glu-A3 were observed at the bottom (Figure 1). The subunits of gliadin coded by Glu-B3 and the presence of $1 \mathrm{~B} / 1 \mathrm{R}$ translocation can be seen in Figure 2.

The HMW-GS of all of the genotypes (Table 2) were found to have four allelic variations in Glu-A1 [subunits $2^{*}(43.8 \%), 1$ (37.5\%), Null (12.5\%), and $1 / 2^{*}(6.2 \%)$ ], five in Glu-B1 [subunits $7+9(50.0 \%), 7+8(37.5 \%)$, and $17+18(12.5 \%)]$, and four in Glu-D1 [subunits $5+10$ (81.3\%), $2+12(18.7 \%)$ ]. The LMWGS were found to have three allelic variations in Glu-A3, with a

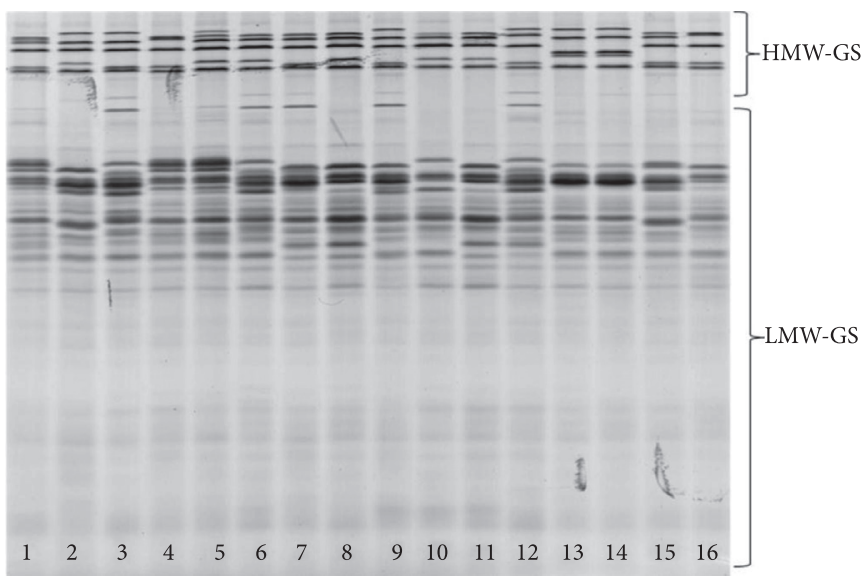

Figure 1. SDS-PAGE separation of the glutenin subunits of the 16 wheat genotypes. (1) T 091028, (2) T 091015, (3) T 091031, (4) T 091008, (5) T 091088, (6) T 091027, (7) LD 101108, (8) T 091056, (9) T 091069, (10) T 091033, (11) T 081099, (12) T 091006, (13) IPR Catuara TM, (14) IPR 85, (15) IPR 130, and (16) IAPAR 78. predominance of the $c$ subunit (56.3\%), followed by $d(25.0 \%)$, and $b(18.7 \%)$.

The subunits of gliadin showed five alleles in Glu-B3 (Table 2), $b(33.3 \%), h(25.0 \%), e(16.7 \%), f(16.7 \%)$, and $g(8.3 \%)$. The study also revealed the presence of the $1 \mathrm{~B} / 1 \mathrm{R}$ translocation in T 091099, T 091033, and T 091056 lines, as well as in the IAPAR 78 cultivar.

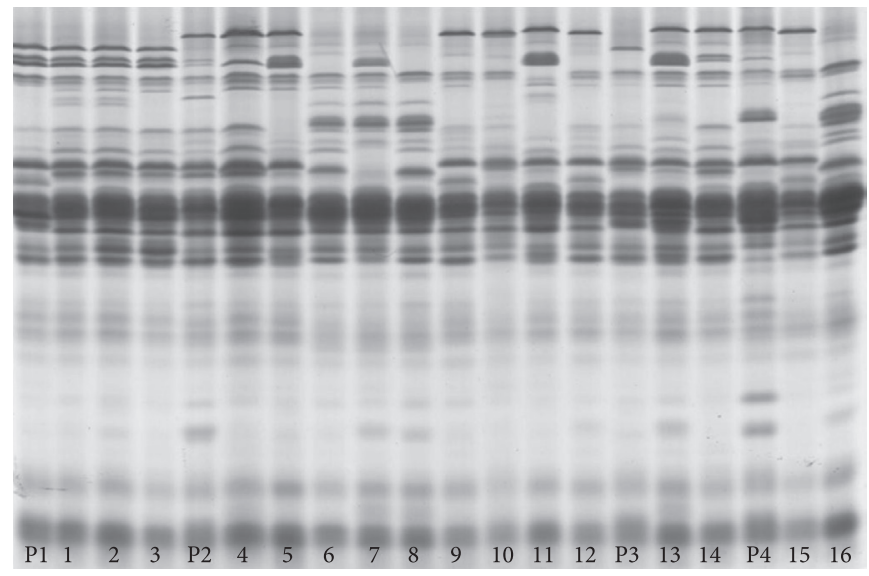

Figure 2. SDS-PAGE separation of the gliadin subunits in 16 wheat genotypes. (P1) standard subunit $h,(1) \mathrm{T} \mathrm{091028,} \mathrm{(2)} \mathrm{T} \mathrm{091008,} \mathrm{(3)}$ T 091088, (P2) standard subunit $f(4)$ T 091069, (5) T 091006, (6) IAPAR 78, (7) T 091033, (8) T 081099, (9) IPR 85, (10) T 091015, (11) T 091031, (12) IPR Catuara TM, (P3) standard subunit $i,(13) \mathrm{T}$ 091027, (14) LD 101108, (P4) standard subunit e and the presence of the 1A/1R translocation, (15) IPR 130, and (16) T 091056.

Table 2. Allelic frequencies and the effect of HMW-GS and LMW-GS on the quality parameters of the 16 genotypes.

\begin{tabular}{|c|c|c|c|c|c|c|c|c|}
\hline Locus & Subunit & Freq. (\%) & PC (\%) & $\mathrm{FN}(\mathrm{sec})$ & SDS-SV $(\mathrm{mL})$ & SI & MTS (g) & $\mathrm{HW}(\mathrm{Kg} / \mathrm{hL})$ \\
\hline \multirow[t]{4}{*}{ Glu-A1 } & 1 & 37.5 & $13.7^{\mathrm{a}}$ & $560^{\mathrm{b}}$ & $13.4^{\mathrm{ab}}$ & $0.9^{\mathrm{a}}$ & $4.3^{\mathrm{a}}$ & $79.5^{\mathrm{a}}$ \\
\hline & $2^{*}$ & 43.8 & $14.3^{\mathrm{a}}$ & $580^{\mathrm{b}}$ & $12.1^{\mathrm{bc}}$ & $0.8^{\mathrm{a}}$ & $3.9^{\mathrm{b}}$ & $79.4^{\mathrm{a}}$ \\
\hline & $1 / 2^{*}$ & 6.2 & $15.4^{\mathrm{a}}$ & $700^{\mathrm{ab}}$ & $13.5^{\mathrm{a}}$ & $0.8^{\mathrm{a}}$ & $3.6^{\mathrm{b}}$ & $77.8^{\mathrm{a}}$ \\
\hline & $\mathrm{N}$ & 12.5 & $13.6^{\mathrm{a}}$ & $615^{a}$ & $10.6^{c}$ & $0.7^{\mathrm{a}}$ & $3.7^{\mathrm{b}}$ & $81.1^{\mathrm{a}}$ \\
\hline \multirow[t]{3}{*}{ Glu-B1 } & $17+18$ & 12.5 & $13.1^{\mathrm{b}}$ & $571^{\mathrm{a}}$ & $13.9^{\mathrm{a}}$ & $1.0^{\mathrm{a}}$ & $4.8^{\mathrm{a}}$ & $81.5^{\mathrm{a}}$ \\
\hline & $7+8$ & 37.5 & $14.9^{\mathrm{a}}$ & $596^{\mathrm{a}}$ & $13.2^{\mathrm{a}}$ & $0.8^{\mathrm{a}}$ & $3.9^{\mathrm{b}}$ & $78.6^{\mathrm{b}}$ \\
\hline & $7+9$ & 50 & $13.7^{\mathrm{b}}$ & $579^{a}$ & $11.55^{\mathrm{b}}$ & $0.8^{\mathrm{a}}$ & $3.9^{\mathrm{b}}$ & $79.7^{\mathrm{ab}}$ \\
\hline \multirow[t]{2}{*}{ Glu-D1 } & $5+10$ & 81.3 & $14.2^{\mathrm{a}}$ & $588^{\mathrm{a}}$ & $12.8^{\mathrm{a}}$ & $0.8^{\mathrm{a}}$ & $4.1^{\mathrm{a}}$ & $79.2^{\mathrm{a}}$ \\
\hline & $2+12$ & 18.7 & $13.4^{\mathrm{a}}$ & $566^{\mathrm{a}}$ & $11.0^{\mathrm{b}}$ & $0.7^{\mathrm{a}}$ & $3.8^{\mathrm{b}}$ & $81.9^{\mathrm{a}}$ \\
\hline \multirow[t]{3}{*}{ Glu-A3 } & $\mathrm{b}$ & 18.7 & $13.0^{\mathrm{b}}$ & $562^{\mathrm{b}}$ & $10.7^{\mathrm{b}}$ & $0.7^{\mathrm{a}}$ & $3.8^{\mathrm{b}}$ & $80.0^{\mathrm{a}}$ \\
\hline & c & 56.3 & $14.1^{\mathrm{a}}$ & $608^{\mathrm{a}}$ & $12.9^{\mathrm{a}}$ & $0.8^{\mathrm{a}}$ & $4.0^{\mathrm{b}}$ & $79.6^{\mathrm{a}}$ \\
\hline & $\mathrm{d}$ & 25 & $14.7^{\mathrm{a}}$ & $648^{a}$ & $12.9^{\mathrm{a}}$ & $0.8^{\mathrm{a}}$ & $4.2^{\mathrm{a}}$ & $79.1^{\mathrm{a}}$ \\
\hline \multirow[t]{5}{*}{ Glu-B3 } & $\mathrm{b}$ & 33.3 & $13.0^{c}$ & $551^{\mathrm{c}}$ & $13.2^{\mathrm{a}}$ & $0.9^{\mathrm{a}}$ & $4.5^{\mathrm{a}}$ & $80.3^{\mathrm{a}}$ \\
\hline & e & 16.7 & $15.5^{\mathrm{a}}$ & $629^{\mathrm{ab}}$ & $12.5^{\mathrm{a}}$ & $0.8^{\mathrm{a}}$ & $4.4^{\mathrm{a}}$ & $78.4^{\mathrm{a}}$ \\
\hline & $\mathrm{f}$ & 16.7 & $13.8^{\mathrm{bc}}$ & $543^{c}$ & $13.5^{\mathrm{a}}$ & $0.8^{\mathrm{a}}$ & $3.7^{\mathrm{b}}$ & $80.5^{\mathrm{a}}$ \\
\hline & g & 8.3 & $13.9^{\mathrm{bc}}$ & $564^{\mathrm{bc}}$ & $11.98^{\mathrm{a}}$ & $1.0^{\mathrm{a}}$ & $3.8^{\mathrm{a}}$ & $77.7^{\mathrm{a}}$ \\
\hline & $\mathrm{h}$ & 25 & $14.2^{\mathrm{b}}$ & $682^{\mathrm{a}}$ & $14.1^{\mathrm{a}}$ & $0.7^{\mathrm{a}}$ & $3.7^{\mathrm{b}}$ & $78.8^{\mathrm{a}}$ \\
\hline \multirow[t]{2}{*}{$1 \mathrm{~B} / 1 \mathrm{R}$} & No $1 \mathrm{~B} / 1 \mathrm{R}$ & 75 & $14.1^{\mathrm{a}}$ & $604^{\mathrm{a}}$ & $12.9^{\mathrm{a}}$ & $0.8^{\mathrm{a}}$ & $4.1^{\mathrm{a}}$ & $79.4^{\mathrm{a}}$ \\
\hline & 1B/1R & 25 & $14.4^{\mathrm{a}}$ & $547^{\mathrm{b}}$ & $11.4^{\mathrm{b}}$ & $0.7^{\mathrm{a}}$ & $3.8^{\mathrm{b}}$ & $79.2^{\mathrm{b}}$ \\
\hline
\end{tabular}

${ }^{a}$ Different letters in the same column for each locus differ significantly ( $\left.\mathrm{p} \leq 0.05\right)$. Freq.: Frequency; PC: Protein content; FN: Falling number. SDS-SV: Sedimentation volume; SI: Sedimentation index; MTS: Mass of 1000 seeds. HW: Hectoliter weight. 
Table 3. Composition of HMW-GS and LMW-GS in the 16 genotypes detected by SDS-PAGE.

\begin{tabular}{|c|c|c|c|c|c|c|c|}
\hline Genotype & Glu-A1 & Glu-B1 & Glu-D1 & $\mathrm{TS}^{\mathrm{a}}$ & Glu-A3 & GluB-3 & $\mathrm{T}^{\mathrm{b}}$ \\
\hline IAPAR 78 & $\mathrm{~N}$ & $7+9$ & $2+12$ & 5 & c & & $1 \mathrm{~B} / 1 \mathrm{R}$ \\
\hline IPR 130 & $2^{*}$ & $7+9$ & $5+10$ & 9 & $\mathrm{~b}$ & $\mathrm{~b}$ & \\
\hline IPR 85 & 1 & $17+18$ & $5+10$ & 10 & c & $\mathrm{b}$ & \\
\hline IPR Catuara TM & 1 & $17+18$ & $5+10$ & 10 & c & $\mathrm{b}$ & \\
\hline LD 101108 & $2^{*}$ & $7+9$ & $5+10$ & 9 & c & $\mathrm{f}$ & \\
\hline Т 081099 & $2^{*}$ & $7+8$ & $5+10$ & 7 & $\mathrm{~b}$ & & $1 \mathrm{~B} / 1 \mathrm{R}$ \\
\hline Т 091006 & 1 & $7+9$ & $2+12$ & 7 & d & $\mathrm{f}$ & \\
\hline Т 091008 & $\mathrm{~N}$ & $7+9$ & $2+12$ & 5 & c & $\mathrm{h}$ & \\
\hline Т 091015 & 1 & $7+8$ & $5+10$ & 10 & c & $\mathrm{b}$ & \\
\hline Т 091027 & $2^{*}$ & $7+8$ & $5+10$ & 10 & d & $\mathrm{e}$ & \\
\hline Т 091028 & $2^{*}$ & $7+9$ & $5+10$ & 9 & $\mathrm{~b}$ & $\mathrm{~h}$ & \\
\hline Т 091031 & 1 & $7+9$ & $5+10$ & 9 & $\mathrm{~d}$ & e & \\
\hline Т 091033 & $2^{*}$ & $7+8$ & $5+10$ & 7 & d & & $1 \mathrm{~B} / 1 \mathrm{R}$ \\
\hline Т 091056 & $2^{*}$ & $7+8$ & $5+10$ & 7 & c & & $1 \mathrm{~B} / 1 \mathrm{R}$ \\
\hline Т 091069 & 1 & $7+9$ & $5+10$ & 9 & c & g & \\
\hline Т 091088 & $1 / 2^{*}$ & $7+8$ & $5+10$ & 10 & c & $\mathrm{h}$ & \\
\hline
\end{tabular}

${ }^{\mathrm{a}} \mathrm{TS}=$ total score; ${ }^{\mathrm{b}} \mathrm{T}=1 \mathrm{~B} / 1 \mathrm{R}$ Translocation.

The total score (TS) of the genotypes varied from 5 to 10 (Table 3). The scores 9 and 10 were the most frequent due to the higher frequency of $2^{*}$ allele in Glu-A1, $7+9$ alleles in Glu-B1, and $5+10$ alleles in Glu-D1. There was a positive correlation between the TS and the volume of sedimentation $(r=0.521)$, SI $(r=0.510)$, and the MTS $(r=0.510)$. The TS has been used as a parameter for selecting lines in Brazilian wheat breeding programs.

Table 2 shows the effect on each subunit present in the different loci on the physicochemical parameters. There were no significant differences in the PC, HW, and SI among the alleles of Glu-A1, while the MTS was higher in the allele 1 than in the other alleles in this subunit. Also, there was no significant difference in the SDS-SV between alleles 1 and $2^{*}$. Liang et al. (2010) did not observe significant differences in the SDS-SV, SI, development time of dough, and gluten strength between alleles 1 and $2^{*}$, which suggests that they have a positive effect on the strength and rheological properties of the dough. Oury et al. (2009) have also reported that alleles 1 and $2^{\star}$ are better qualified for bread-making than the null subunit.

In Glu-B1, the highest MTS and HW were detected in the $17+18$ alleles, and there were no significant differences between the SIs and FN values of the different alleles. The lowest SDS-SV was detected in the $7+9$ alleles, results which agree with those of Bedo et al. (1998).

The SDS-SV and MTS were higher in the $5+10$ alleles in Glu-D1 than in the $2+12$ alleles. Similar results were found by Payne et al. (1987), Luo et al. (2001), Liang et al. (2010) and $\mathrm{Li}$ et al. (2010). There were no significant differences between the PC, FN values, and the HW of the alleles in Glu-D1.

In the Glu-A3 from gliadin, there were no differences between the SIs and HWs of the alleles, but a lower PC, lower FN value, and lower SDS-SV were detected in the $b$ allele, when compared to $c$ and $d$ alleles. There were no differences between the MTS values in $b$ and $c$ alleles, which were lower than in $d$ allele. Luo et al. (2001) reported that the $d$ allele would be a good alternative for selecting genotypes from Chinese wheat. In Glu-B3, there were no significant differences between the SDS-SV, SI, and HWs of the alleles, but MTS was higher in the $b, e$, and $g$ alleles than in the other alleles. The lowest PC was detected in the $b$ allele, while the highest was detected in the $e$, and the highest FN values were detected in $h$ and $e$ alleles. Luo et al. (2001) reported that the $g$ and $b$ alleles are desirable in Chinese wheat breeding programs due to their positive effect on the dough rheological properties. Wang et al. (2009) observed that the subunits of gliadin are important in selecting wheat lines of bread-making quality.

The genotypes with $1 \mathrm{~B} / 1 \mathrm{R}$ translocation were found to have the $7+8$ and $7+9$ alleles in Glu-1B (Table 3 ). According to Peña et al. (1990), the $7+9$ bands correlate with the presence of $1 \mathrm{~B} / 1 \mathrm{R}$. These genotypes had lower FN values, SDS-SV, MTS, and HW when compared with those without translocation (No 1B/1R, Table 2). According to Zanatta et al. (2002), the presence of translocation has a positive effect on resistance to diseases and pests and a negative effect on bread-making quality.

Among the alleles present in the different loci, the 1 and $2^{*}$ in Glu-A1 , $17+18$ and $7+8$ in Glu-B1, $5+10$ in Glu-D1, $d$ in Glu-A3, and $b$ in Glu-B3 have all been described as having a positive effect on bread-making quality (BRANLARD et al., 2003). He et al. (2005) studied the effects of the subunits of each locus on gluten quality for bread-making from Chinese wheat. These authors found that the combinations 1 of Glu-A1, $7+8$ of Glu-B1, $5+10$ of Glu-D1, and $d$ of Glu-A3 could contribute to an improved quality of wheat genotypes.

\subsection{Analysis of principal components}

An analysis of principal components was used to determine the quality characteristics of the genotypes based on their physicochemical properties. TS, SDS-SV, and SI made up the 
first component, and protein content and HW made up the second component. These two components retained 41.50 and $29.15 \%$ of the initial sample variability, respectively.

The different genotypes were grouped into four quadrants and are presented in Figure 3. The T 091088, T 091031, and T 091027 lines, which stood out because of their higher protein content $(>17 \%)$, were grouped together in quadrant I. According to Franceschi et al. (2009), protein content has quantitative characteristics that are expressed by a large number of genes, which are influenced by the environment. Protein content may significantly vary for any given cultivar depending on the environmental conditions (climate and soil) in which the grain is cultivated, as well as on genetic control (TURNBULL; RAHMAN, 2002). Protein content has been positively correlated with gluten strength, farinographic parameters, gluten content, and baking parameters (BRANLARD et al., 1991). However, Denčić, Mladenov and Kobiljski (2011) found no correlation between protein content and baking parameters. In addition to the quantity, the quality of proteins is also important for the quality of the bread wheat genotype.

The T 091056, T 091008, LD 101108, and T 081099 lines, which had low MST, high HW, and intermediate values in the other parameters, were grouped together in quadrant II. The T 091028, T 091006, IPR 130, and IAPAR 78 genotypes that had low SDS-SV, SI, and PC and high HW were grouped together in quadrant III. The IPR Catuara TM, IPR 85, T 091015, and T 091069 genotypes that had high SDS-SV and SI were grouped together in quadrant IV, which suggests their possibly superior quality. Felício et al. (1998) observed a strong correlation between SDS-SV and the deformation energy of dough (W), a result which suggests that this small scale-test is useful for a preliminary selection of genotypes in an attempt to focus on quality. Mittelmann et al. (2000) evaluated the genetic heritage and physicochemical characteristics (SDS-SV, SI, and protein

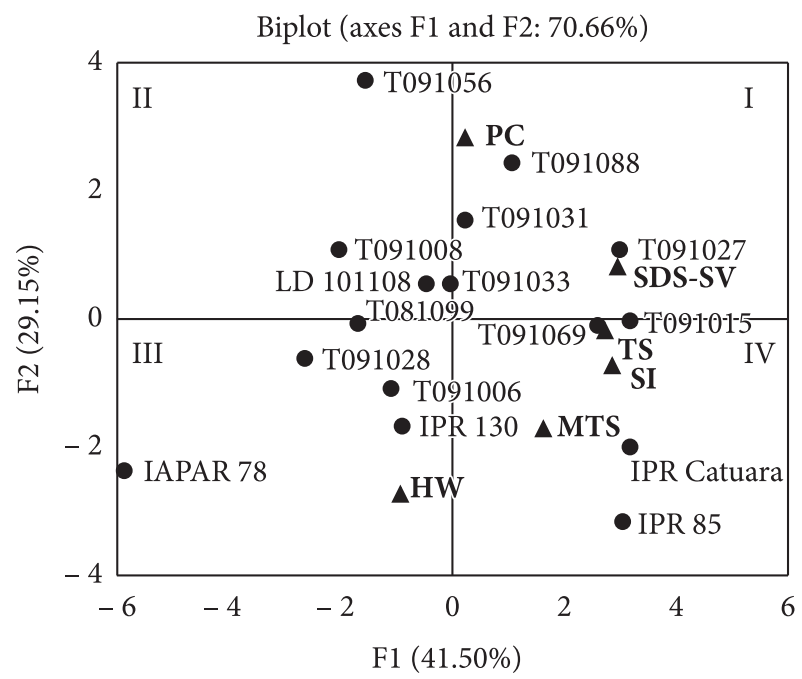

Figure 3. Principal component analysis of the physicochemical parameters of the grains and HMW-GS of 16 wheat genotypes. $\Delta$ Variables: PC: Protein content; SDS-SV: Sedimentation volume; SI: Sedimentation index; MTS: Mass of 1000 seeds; and HW: Hectoliter weight. - Genotypes. content) in 10 crossings that involved five cultivars. These authors observed a strong correlation between SDS-SV and SI, and they suggested that there is no difference between using one criterion or another in the selection process. However, it should be noted that the correlation of these tests with other parameters of quality is also important. In the present study, SDS-SV correlated only with the SI. The SI, in turn, correlated with the TS.

The genotypes of quadrant IV were also found to have higher MTS. There is a positive correlation between grain size and flour yield (POSNER, 2000), which suggests that these genotypes could have a higher flour yield. Schmidt et al. (2009) studied the genetic variability of wheat genotypes with characteristics that were used to indicate quality and industrial yield. They reported that MTS was significantly correlated with $\mathrm{FN}$ and protein content in the genotypes studied. They also observed that MTS and HW did not expressively contribute to an understanding of the factors that affect the industrial quality of wheat.

Cluster analyses allowed us to outline the representative dendrogram (Figure 4) and to classify the genotypes into three groups: Group I constituted of two cultivars (IAPAR 78 and IPR 130) and four lines (T 091008, T 081099, T 091006, and T 091028); Group II constituted of six lines (T 091056, T 091033 , T 091031, LD 101108, T 091088, and T 091027); and Group III constituted of two cultivars (IPR 85 and IPR Catuara TM) and two lines (T 091069 and $\mathrm{T}$ 091015).

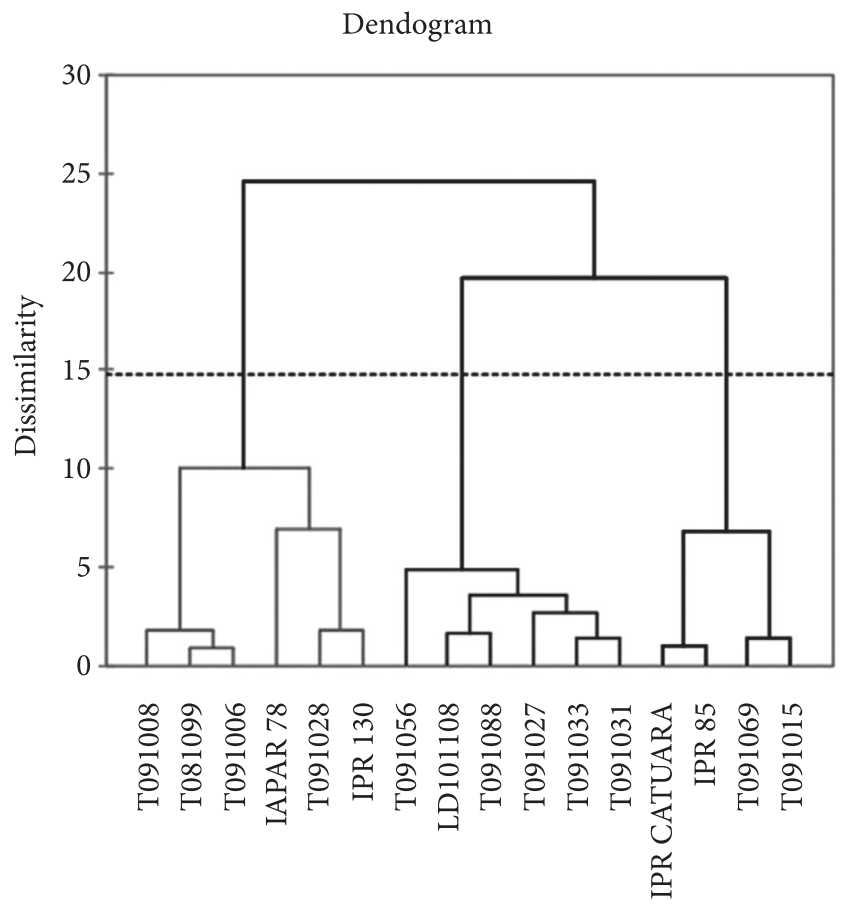

Figure 4. Dendrogram resulting of the analysis of 16 wheat genotypes based on the physicochemical parameters of the grains and evaluation of HMW-GS, LMW-GS and gliadins subunits. Group I: T 091008, T 081099, T 091006, IAPAR 78, T 091028 and IPR 130. Group II: T 091056, LD 101108, T 091088, T 091027, T 091033, and T 091031. Group III: IPR Catuara, IPR 85, T 091069, and T 091015. 
The $7+9$ alleles of Glu-B1 were predominant in Group I, with the exception of the T 081099 line, which was probably in this group due to presence of the allele $b$ of Glu-A3 and the $1 \mathrm{~B} / 1 \mathrm{R}$ translocation. This group also presented the null alleles of Glu-A1, and the $2+12$ alleles of Glu-D1, which resulted in lower TS when compared to that of the other groups. The T 091008, T 081099, and T 091006 lines originated from different research institutions (IAPAR, EMBRAPA, and OR seeds), and the IAPAR 78 and IPR 130 cultivars, as well as the T 091028 line, were all found to possess materials from Mexican, American, and Brazilian germplasm banks in their crossing, and the crossing of these materials was performed at the IAPAR.

The $2^{*}$ allele of Glu-A1, the $5+10$ alleles of Glu-D1, and the $c$ and $d$ alleles of Glu-A3 were predominant in Group II. The T 091088 line presented the 1 and $2^{\star}$ alleles at the same time, which characterizes it as a polymorphism that should be investigated in a more detailed study since this line was obtained with materials from different research centers (IAPAR, EMBRAPA, OR seeds). The T 091031 line was obtained from crossings with materials from OR seeds and from EMBRAPA, and the LD 101108 line was obtained from crossings with materials from OR seeds and from IAPAR. The other lines of this group were obtained from crossings with materials from EMBRAPA and IAPAR.

The genotypes that presented $1 \mathrm{~B} / 1 \mathrm{R}$ translocation were in different groups (IAPAR 178 and T081099 in Group I; T091033 and T091056 in Group II) since the genotypes were obtained from different crossings. Therefore, the translocation alone is not enough to characterize these materials, and the HMW-GS and LMW-GS should be taken into account as well.

Group III showed the 1 allele of Glu-A1, $5+10$ alleles of Glu-D1, $c$ allele of Glu-A3, and $b$ and $g$ alleles of Glu-B3. The genotypes from this group were obtained with materials from IAPAR, and the two cultivars participating in this group are associated with high productivity and excellent dough rheological properties. Thus, the lines of this group may have the same characteristics as their provenances, but further studies should be conducted to confirm that these materials are superior in quality.

Comparing the physicochemical analyses of wheat grains from the three groups revealed that Group I had low SDS-SV and MTS, higher HW, and an intermediate SI. Group II had intermediate values of SDS-SV, SI, MTS, and HW, and high protein content. Group III had the best characteristics of quality, with higher TS, SDS-SV, SI, and MTS.

\section{Conclusion}

This study provided a better understanding of the effects of HMW-GS and LMW-GS on the physicochemical characteristics of wheat. The $2^{\star}$ allele from Glu-A1, $7+9$ alleles from Glu-B1, $5+10$ alleles from Glu-D1, $c$ allele from Glu-A3, and $b$ allele from Glu-B3 were more frequent in the different genotypes. The IPR 85, IPR Catuara TM, T 091015, and T 091069 genotypes that showed the 1 allele (Glu-A1), $5+10$ alleles (Glu-D1), $c$ allele (Glu-A3), and $b$ allele (Glu-B3), with the exception of T 091069 that possessed the $g$ instead of $b$ in the Glu-B3, stood out from the others, which indicate their possibly superior grain quality, with higher SDS-SV, SI, and MTS. In breeding programs, these subunits are preferred for the development of new materials with gluten strength and extensibility that are adequate for baked goods.

\section{Acknowledgements}

The authors gratefully acknowledge CNPq (The National Council for Scientific and Technological Development) for the research scholarship granted to the first author.

\section{References}

AMERICAN ASSOCIATION OF CEREAL CHEMISTS - AACC. Approved Methods of the American Association of Cereal Chemists. 10th ed. AACC, 2000.

BEDO, Z. et al. Breeding for bread-making quality using old Hungarian wheat varieties. Euphytica, v. 100, p. 179-182, 1998. http://dx.doi. org/10.1023/A:1018373805161

BRANLARD, G.; DARDEVET, M. Diversity of grain protein and bread wheat quality. II. Correlation between high molecular subunits of glutenin and flour quality characteristics. Journal of Cereal Science, v. 3, p. 345-354, 1985. http://dx.doi.org/10.1016/S07335210(85)80007-2

BRANLARD, G. et al. Comparison of 46 technological breeding criteria used bread wheat quality evalution. Journal Genetic Breeding, v. 45 , p. $263-280,1991$.

BRANLARD, G. et al. Allelic diversity HMW and LMW glutenin subunits and Omega-gliadins in French bread wheat (Triticum aestivum L.). Genetic Resources and Crop Evolution, v. 50, p. 669-679, 2003. http://dx.doi.org/10.1023/A:1025077005401

BRASIL. Ministério da Agricultura, Pecuária e Abastecimento. Regras para análise de sementes. Brasília: MAPA, 2009. p. 398.

BRASIL. Ministério da Agricultura, Pecuária e Abastecimento. Instrução Normativa no 38,30 de novembro de 2010. Regulamento Técnico de Trigo. Diário Oficial da República Federativa do Brasil, Brasília, DF, 01 dez. 2010. Seção 1, n. 229, p. 2-4.

COSTA, M. G. et al. Qualidade tecnológica de grãos e farinhas de trigo nacionais e importados. Ciência e Tecnologia de Alimentos, v. 28 , n. 1, p. 220-225, 2008. http://dx.doi.org/10.1590/S010120612008000100031

DENČIĆ, S.; MLADENOV, N.; KOBILJSKI, B. Effects of genotype and environment on breadmaking quality in wheat. International Journal of Plant Production, v. 5, n. 1, p. 71-82, 2011.

FELÍCIO, J. C. et al. Interação entre genótipos e ambiente na produtividade e na qualidade tecnológica dos grãos de trigo no estado de São Paulo. Bragantia, v. 57, n. 1, 1998. http://dx.doi. org/10.1590/S0006-87051998000100017

FRANCESCHI, L. et al. Fatores pré-colheita que afetam a qualidade tecnológica de trigo. Ciência Rural, v. 39, n. 5, p. 1624-1631, 2009. http://dx.doi.org/10.1590/S0103-84782009005000060

GIANIBELLI, M. C. et al. Biochemical, genetic, and molecular characterization of wheat endosperm proteins. Cereal Chemistry, v. 77, p. 1-20, 2001.

GUARIENTI, E. M. Qualidade industrial de trigo. Passo Fundo: EMBRAPA-CNPT, 1996. 36 p.

GUPTA, R. B.; BEKES, F.; WRIGLEY, C. W. Prediction of physical dough properties from glutenin subunit composition in bread wheats: correlation studies. Cereal Chemistry, v. 68 , p. 328 333, 1991. 
GUPTA, R. B. et al. Allelic variation at glutenin subunit and gliadin loci, Glu-1, Glu-3 and Gli-1, of common wheats. 1 . Its additive and interaction effects on dough properties. Journal of Cereal Science, v. 19, p. 9-17, 1994. http://dx.doi.org/10.1006/jcrs.1994.1003

GUTKOSKI, L. C. et al. Efeito do período de maturação de grãos nas propriedades físicas e reológicas de trigo. Ciência e Tecnologia de Alimentos, v. 28, n. 4, p. 888-894, 2008. http://dx.doi.org/10.1590/ S0101-20612008000400019

GUTKOSKI, L. C. Controle de qualidade de grãos e farinhas de cereais. In: SIMPÓSIO DE NUTRIÇÃO, CIÊNCIA E TECNOLOGIA DE ALIMENTOS, 6., 2009, Passo Fundo. Anais... Passo Fundo: UPF, 2009. p. 1-29.

HE, X. Y. et al. Composition of HMW and LMW glutenin subunits and their affects on dough properties, pan bread, and noodle quality of Chinese bread wheats. Cereal Chemistry, v. 82, p. 345-350, 2005. http://dx.doi.org/10.1094/CC-82-0345

HERNÁNDEZ, Z. J. E. et al. Influence of high and low molecular weight glutenins on stress relaxation of wheat kernels and the relation to sedimentation and rheological properties. Journal of Cereal Science, v. 55, p. 344-350, 2012. http://dx.doi.org/10.1016/j. jcs.2012.01.009

HOSENEY, R. C. Principios de Ciencia y Tecnología de los Cereales. Zaragoza: Editorial Acribia S.A.,1991. 1321 p.

KTENIOUDAKI, A.; BUTLER, F.; GALLAGHER, E. Studying the dough characteristics of Irish wheat varieties I. Rheological properties and prediction of baking volume. LWT- Food Science and Technology, v. 44, n. 3, p. 594-601, 2011.

LI, Y. et al. Development of introgression lines with 18 alleles of glutenin subunits and evaluation of the effects of various alleles on quality related traits in wheat (Triticum aestivum L.). Journal of Cereal Science, v. 51, p. 127-133, 2010. http://dx.doi.org/10.1016/j. jcs.2009.10.008

LIANG, D. et al. Characterization of CIMMYT bread wheats for highand low-molecular weight glutenin subunits and other qualityrelated genes with SDS-PAGE, RP-HPLC and molecular markers. Euphytica, v. 172, n. 2, p. 235-50, 2010. http://dx.doi.org/10.1007/ s10681-009-0054-x

LUO, C. et al. Comparison of low- and high molecular-wheight wheat glutenin alleles effects on flour quality. Treoretical and applied genetics, v. 102, p. 1088-1098, 2001.

MANDARINO, J. M. G. Aspectos importantes para qualidade do trigo. Londrina: EMBRAPA/CNPSo, 1993. 32 p.

MITTELMANN, A. et al. Herança de caracteres do trigo relacionados à qualidade de panificação. Pesquisa Agropecuária Brasileira, v. 35, n. 5, p. 974-983, 2000. http://dx.doi.org/10.1590/S0100204X2000000500015

OURY, F. et al. The prediction of bread wheat quality: joint use of the phenotypic information brought by technological tests and the genetic information brought by HMW and LMW glutenin subunits. Euphytica, v. 171, n. 1, 2009.

PAYNE, P. I. et al. Wheat storage proteins: Their genetics and their potential for manipulation by plant breeding. Philosophical Transactions of the Royal Society B: Biological Sciences, v. 304, p. 359-371, 1984. http://dx.doi.org/10.1098/rstb.1984.0031

PAYNE, P. I. et al. Allelic variation of glutenin subunits and gliadins and its effect on breadmaking quality in wheat: analysis of F5 progeny from "Chinese Spring" X "Chinese Spring” (Hope 1A). Journal of Cereal Science, v. 6, p. 103-118, 1987. http://dx.doi.org/10.1016/ S0733-5210(87)80047-4

PEÑA, R. J. et al. Variation in quality characteristics associated whit some spring $1 \mathrm{~B} / 1 \mathrm{R}$ translocation wheats. Journal of Cereal Science, v. 12, p. 105-112, 1990. http://dx.doi.org/10.1016/S07335210(09)80092-1
PEÑA, R. J.; GONZÁLEZ, H. G.; CERVANTES, F. Relationship between Glu-D1/Glu-B3 allelic combinations and bread-making quality related parameters commonly used in wheat breeding. In: GLUTEN WORKSHOP, 8., 2004. Cambridge. Proceedings... Cambridge: Royal Society, 2004. p. 156-157.

PEÑA, E. et al. Relationship between common wheat (Triticum aestivum L.) gluten proteins and dough rheological properties. Euphytica, v. 143, p. 169-177, 2005. http://dx.doi.org/10.1007/ s10681-005-3157-z

POSNER, E. S. Wheat. In: KULP, K.; PONTE, J. G. Handbook of cereal science and technology. 2nd ed. New York: Marcel Dekker, 2000. p. 1-29.

PRABHASANKAR, P.; SUDHA, M. L.; RAO, P. Quality characteristics of wheat flour milled streams. Food Research International, v. 33, p. 381-386, 2000. http://dx.doi.org/10.1016/S0963-9969(00)00059-4

SCHMIDT, D. A. M. et al. Correlações entre gluteninas de alto peso molecular e técnicas que avaliam a qualidade de panificação em trigos hexaplóides (Triticum aestivum). In: CONGRESSO DE INICIAÇÃO CIENTIFICA, 14., 2005, Pelotas. Anais... Pelotas:UFPEL, 2005.

SCHMIDT, D. A. M. et al. Variabilidade genética em trigos brasileiros a partir de caracteres componentes da qualidade industrial e produção de grãos. Bragantia, v. 68, n. 1, p. 43-52, 2009. http:// dx.doi.org/10.1590/S0006-87052009000100006

SHEWRY, P. R. et al. The high molecular weight subunits of wheat glutenin and their role in determining wheat processing properties. Advances in Food and Nutrition Research, v. 45, p. 219-302, 2003. http://dx.doi.org/10.1016/S1043-4526(03)45006-7

SINGH, N. K.; SHEPHERD, K. W.; CORNISH, G. B. A simplified SDS-PAGE procedure for separating LMW subunits of glutenin. Journal of Cereal Science, v. 14, p. 203-208, 1991. http://dx.doi. org/10.1016/S0733-5210(09)80039-8

SMANHOTTO, A. et al. Características físicas e fisiológicas na qualidade industrial de cultivares e linhagens de trigo e triticale. Revista Brasileira de Engenharia Agrícola Ambiental, v. 10 , n. 4 , p. $867-872,2006$. http://dx.doi.org/10.1590/S141543662006000400013

STATSOFT. STATISTICA 7.0 for Windows - Computar program manual. Tulsa: Statsoft, Inc., 2007. CD-ROM.

TURNBULL, K. M.; RAHMAN, S. Endosperm texture in wheat. Journal of Cereal Science, v. 36, p. 327-337, 2002. http://dx.doi. org/10.1006/jcrs.2002.0468

WANG, L. H. et al. Characterization of low-molecular-weight glutenin subunit Glu-B3 genes and development of STS markers in common wheat (Triticm aestivum L.). Theoretical and Applied Genetics, v. 118, n. 3, 2009. http://dx.doi.org/10.1007/s00122-008-0918-9

WEEGLES, P. L.; HAMER, R. J.; SCHOFIELD, J. D. Critical review functional properties of wheat glutenin. Journal of Cereal Science, v. 23, p. 1-18, 1996. http://dx.doi.org/10.1006/jcrs.1996.0001

WILLIAMS, P. et al. Crop quality evaluation methods and guidelines. 2nd ed. Aleppo: ICARDA, 1988. 145 p.

ZANATTA, A. C. A. et al. Uso de marcadores proteicos na seleção de trigo (Triticum aestivum $\mathrm{L}$. em. Thell.) com qualidade tecnológica superior na Embrapa Trigo. Passo Fundo: Embrapa Trigo, 2002. (Embrapa Trigo. Comunicado Técnico Online, n. 85). Disponível: <http://www.cnpt.embrapa.br/biblio/p_co85.htm>. Acesso: 05 jan. 2012.

ZHENG, W. et al. High frequency of abnormal high molecular weight glutenin alleles in Chinese wheat landraces of the Yangtze-River region. Journal of Cereal Science, v. 54, p. 401-408, 2011. http:// dx.doi.org/10.1016/j.jcs.2011.08.004 